\title{
Emergence and initial development of Cape gooseberry (Physalis peruviana) seedlings with different substrate compositions
}

\author{
Andre Luiz Piva ${ }^{1 \star}$, Eder Junior Mezzalira ${ }^{1}$, Anderson Santin ${ }^{1}$, Daniel Sschwantes ${ }^{1}$, Jeferson \\ Klein ${ }^{1}$, Leandro Rampim ${ }^{1}$, Fabíola Villa ${ }^{1}$, Claudio Yuji Tsutsumi ${ }^{1}$ and Gilmar Antônio Nava ${ }^{2}$ \\ ${ }^{1}$ Universidade Estadual do Oeste do Paraná/ Centro de Ciências Agrárias/ Programa de Pós Graduação em Agronomia. \\ Rua Pernambuco, 1777, CEP: 85960-000. Marechal Cândido Rondon, Paraná, Brazil. \\ ${ }^{2}$ Universidade Tecnológica Federal do Paraná, Campus Dois Vizinhos, Brazil.
}

Accepted 4 December, 2013

\begin{abstract}
The seedlings quality is one of the most important factors in the implantation of new orchards. In this sense, this work aimed to evaluate the emergence and initial development of Cape gooseberry seedlings with different substrate compositions. The experiment was performed in the experimental area of Federal Technological University of Parana, Campus of Dois Vizinhos, Brazil. The experimental design used was a randomize block design, with four replications, being evaluated the following substrates: Soil + chicken manure $(2: 1 \mathrm{v} / \mathrm{v})$; soil + chicken manure + sand $(2: 1: 1)$; soil + humus + vermiculite (2:1:1); soil + humus (2:1) and Macplant ${ }^{\circledR}$ (commercial substrate). The emergence percentage, number of leaves, height of plants, dry mass of root system and dry mass of the shoot system was evaluated. The substrate compound by soil + humus + vermiculite and the substrate compound by soil + humus allowed higher emergence of plants, however not contributing for the development of the Cape gooseberry seedlings. Nevertheless, the substrate with soil + chicken manure and the substrate with soil + chicken manure + sand only provided the initial development of the seedlings. On the other hand, the use of the substrate Macplant ${ }^{\circledR}$ must be avoided in the propagation of this culture.
\end{abstract}

Key words: Exotic fruits, propagation, germination, Macplant ${ }^{\circledR}$, vermiculite.

\section{INTRODUCTION}

The progressive increase of the demand for food is one of the greatest incentives for farmers to increase and diversify their production, in this context, the orcharding has great contribution in the Brazilian scenario, with the addiction of many exotic species (Muniz et al., 2011). The group of small fruits is causing great interest because of the high market value and the low cost of production (Mota, 2006; Rodrigues et al., 2009). In this case, the Cape gooseberry (Physalis peruviana L.) is one of the more recent plants, occupying a considerable area in the production (Lima et al., 2010).

The Cape gooseberry is a plant of the solanaceae family, with indeterminate grow habit and it has caused great interest for production in the south, southwest and northwest states of Brazil (Kuhn et al., 2012; Velasquez et al., 2007; Andrade, 2008). This fruit offer great nutraceutical value, with great quantity of vitamin $A$ and $\mathrm{C}$, among others minerals. In different regions of 
Colombia, the fruit is used in the popular medicine, for purification of blood and relief of throat problems (Chaves et al., 2005).

In relation to the cultivation, for the obtaining more homogeneous orchards the use of seedlings of quality is necessary, however, studies show that, the method of propagation more used for annual fruits like Cape gooseberry is by using seeds, even with high genetic variability (Lima et al., 2010). Díaz et al. (2010) evaluating the emergence of Cape gooseberry seedlings in different substrates, observed that, the coconut fiber is able to replace the peat in the emergence and development of Cape gooseberry.

In order to present seeds with a homogeneous germination and emergence, some factors must be optimized, like the relation between the substrate quantity, hydric availability, thermal proprieties and absence of physical obstacles for the emergence of some species (Ferraz et al., 2005; Castro et al., 2005; WagnerJúnior et al., 2006).

When these factors are improved, the seeds have better conditions for the germination and emergence, and the seedlings better conditions for initial development, creating conditions for new and quality orchards. However, the choice of the substrate composition must be according to the species characteristics (Dias et al., 2008; Brasil, 2009).

Frequently farmers are limited by the use of one or few commercial substrates, normally of high cost and hard access, something very similar occurs in the Southwest region of Parana State, Brazil, where there is a weak technical and commercial support for the horticulture activities. However, it should be noted as favorable aspect to the production of fruit seedlings that in the Southwest region of Parana, it is possible to find many byproducts from the traditional agricultural and livestock activities, as production of grains or animals, which could be used in the formulation of alternatives substrates, meeting the existent requirements for an easy access and low cost product.

There is little technical information about the production of quality seedlings for Cape gooseberry. In this way, this work aimed to evaluate the emergence and initial development of $P$. peruviana $\mathrm{L}$. seedlings with different substrate compositions.

\section{MATERIALS AND METHODS}

The experiment was conducted in the experimental station of orcharding at the Federal Technological University of Parana, Campus of Dois Vizinhos, Dois Vizinhos - Parana, from September to December 2009. The geographic coordinates were $42^{\circ} 25^{\prime} \mathrm{S}$ of latitude and $53^{\circ} 06^{\prime} \mathrm{W}$ of longitude, with an altitude of $520 \mathrm{~m}$, in the eco-climatic region of Southwest Parana, Brazil, with an average temperature for the period of $21^{\circ} \mathrm{C}$ (Inmet, 2012).

The study was conducted in a screen house, and the randomized blocks design was used, with four replications. The plots were formed by 10 poly tubes with capacity of $150 \mathrm{~cm}^{3}$, with five seeds in each tube. The used seeds were collected from mature fruits (yellow/orange color) from $P$. peruviana L. plants.

The seeds were sowed in poly tubes with substrate, being evaluated five substrate compositions. The tested substrates were: Soil + chicken manure $(2: 1 \mathrm{v} / \mathrm{v})$; soil + chicken manure + sand $(2: 1: 1 \mathrm{v} / \mathrm{v} / \mathrm{v})$; soil + humus + vermiculite $(2: 1: 1 \mathrm{v} / \mathrm{v} / \mathrm{v})$; soil + humus $(2: 1 \mathrm{v} / \mathrm{v})$ and Macplant ${ }^{\circledR}$ (commercial substrate). The used soil was a Red Alfisol (USDA classification), which was sieved for the standardization of the particles size. Besides, the manure used was originated from a chicken farm, being also submitted to a sieve for standardization of the particles sizes. Moreover, the humus used was originated from vegetal residues (lettuce, cabbage, kale, etc) and vermiculite (Plantmax ${ }^{\circledR}$ ) used in a medium granulometry.

These substrates were chosen because these are widely used in the production of seedlings of many different fruit and forestry species in Brazil (Severino et al., 2006). The commercial substrate Macplant ${ }^{\circledR}$ has the following characteristic: porosity of $0.20 \mathrm{~cm}^{3}$, humidity of $0.77 \mathrm{~cm}^{3}$ (saturated), density of $0.17 \mathrm{~g} \mathrm{~cm}^{-3}, 440 \mathrm{mg} \mathrm{dm}$ ${ }^{3}$ of $\mathrm{K}, 74 \mathrm{mg} \mathrm{dm}^{-3}$ of $\mathrm{P}$, percentage of organic matter (\% OM) of $20.7 \mathrm{~m} \mathrm{v}^{-1}$ (Pacheco and Franco, 2008).

After the sowing, the tray with the poly tubes was maintained in the screen house during the experiment time. The irrigation was performed on a daily basis according to the observed needs, being held with a Sprinkler System.

The seedlings emergence was monitored trough the counting of the emerged seedlings daily in each experimental unit. Besides, it was considered the beginning of emergence at 14 days after sowing (DAS) when the first seedlings emerged, and the final percentage was obtained in the 25 DAS, according to the norms of analysis of Brasil (2009).

After the end of the seedlings emergence (that is, 25 DAS), the thinning of the seedlings was performed, maintaining only one seedling per poly tube. This moment was considered the start point for the initial develop of the seedlings of Cape gooseberry.

The height of plants was performed using a graduated scale, being also performed the counting of completely expanded leaves. At 90 DAS, the last evaluation of height and number of leaves was performed.

Later, the seedlings were carefully removed from the poly tubes and cut in shoot system and root system. The roots were washed to remove the substrate particles, and the two parts of the plant were dried in an air circulation oven at $65^{\circ} \mathrm{C}$ for $96 \mathrm{~h}$. At the end of this process, the dry mass from the shoot and root systems were obtained. The data were submitted to the variance analysis and the means compared by Tukey test at $5 \%$ of probability, with the statistical software SAS (SAS Institute, 1999).

\section{RESULTS AND DISCUSSION}

In the evaluation of the emergence data, it was verified a higher percentage of emergence of Cape gooseberry seedlings with the substrate vermiculite + soil + humus and with soil + humus, that did not differ statistically among each.

Inferior results were obtained with the commercial substrate Macplant $\AA^{\circledR}$; soil + chicken manure and with soil + sand + chicken manure (Table 1). Possibly the high seedlings emergence obtained with the substrate soil + vermiculite + humus and with soil + humus can be explained by the excellent capacity of water storage performed by the vermiculite and the humus (Alvino and Rayol, 2007). Also the characteristics of the used soil can influence, because it is a clay soil with great water 
Piva et al.

Table 1. Emergence percentage of Cape gooseberry in response to different substrate compositions at Federal Technological University of Parana, Campus of Dois Vizinhos, 2009.

\begin{tabular}{lc}
\hline Substrate & Emergence (\%) \\
\hline Soil + chicken manure (2:1) & $64.5^{\mathrm{c}}$ \\
Soil + chicken manure + sand (2:1:1) & $70.5^{\mathrm{bc}}$ \\
Soil + humus + vermiculite $(2: 1: 1)$ & $94.5^{\mathrm{a}}$ \\
Soil + humus (2:1) & $88.0^{\mathrm{ab}}$ \\
Macplant & (commercial substrate) \\
Pr>Fc & $52.5^{\mathrm{c}}$ \\
CV $(\%)$ & 0.0001 \\
\hline
\end{tabular}

Means followed by the same letter do not differ statistically by the Tukey test at $5 \%$ of probability.

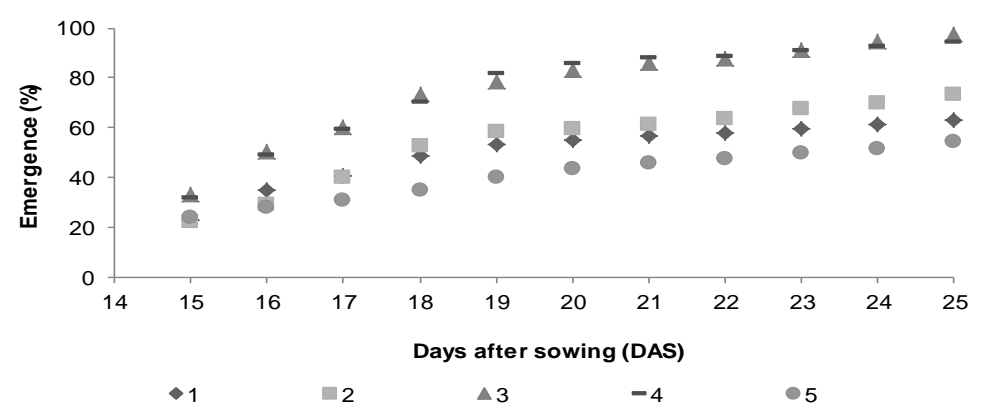

Figure 1. Emergence of Cape gooseberry seedlings in response to different substrate compositions, Federal Technological University of Parana, Campus of Dois Vizinhos, 2009. Substrate 1: Soil + chicken manure $(2: 1 \mathrm{v} / \mathrm{v})$ 2: Soil + chicken manure + sand $(2: 1: 1 \mathrm{v} / \mathrm{v} / \mathrm{v}) ; 3$ : Soil + humus + vermiculite $(2: 1: 1 \mathrm{v} / \mathrm{v} / \mathrm{v}) ; 4$ : Soil + humus $(2: 1 \mathrm{v} / \mathrm{v}) ; 5$ : Macplant ${ }^{\circledR}$ (commercial substrate).

absorption. Besides, the vermiculite and the humus also have a good drainage of the excess of water. These factors possibly allowed a better availability of water and oxygenation for the roots, creating an excellent environment for the activation of enzymes responsible for the hydrolysis of reserve substances in the seeds and for the start of the germination process and emergence of the seedlings (Taiz and Zeiger, 2009).

The obtained data show that, the tested substrates presented higher values for seedlings emergence in relation to the results obtained by Kuhn et al. (2012) that observed an average of $30 \%$. It is supposed that, the chicken manure had caused some compression in the superficial levels of the substrate in the presence of irrigation water, causing a reduction of penetration water in the substrate, occurring a reduction of the level of oxygenation in function of the crust. This fact may had contributed for the reduction of the germination process, providing a reduction on the emergence

Another hypothesis that needs to be analyzed is that, one increase of the substrate temperature near to the seed provided by the process fermentation of chicken manure, may have affected the development of the germination process and emergence. According to what can be observed in the work of Andrade et al. (2006), that the increase of 5 degrees was enough for reducing the mean values of germination of Dalbergia nigra. On the other hand, the commercial substrate Macplant $\AA^{\circledR}$, promoted the drainage of water through the contact with the poly tubes, standardizing its humidity.

Nascimento et al. (2003) observed that, little alterations in the chemical and physical composition or in the biological proprieties of the substrate can influence the germination of different vegetal species, as tomato and pepper, as well as their development. In the same way, the substrate can also cause physical impediment, through large particles, prejudicing the emergence of the seedlings, which have too small and delicate roots, causing poor vigor (Wagner-Junior et al., 2006).

In relation to the seedlings emergence, it was observed that, the beginning of the emergence started at 15 DAS, being this result similar to what was observed by Díaz et al. (2010). The behavior of all the evaluated substrate is observed in Figure 1. Alterations in the emergence 
A

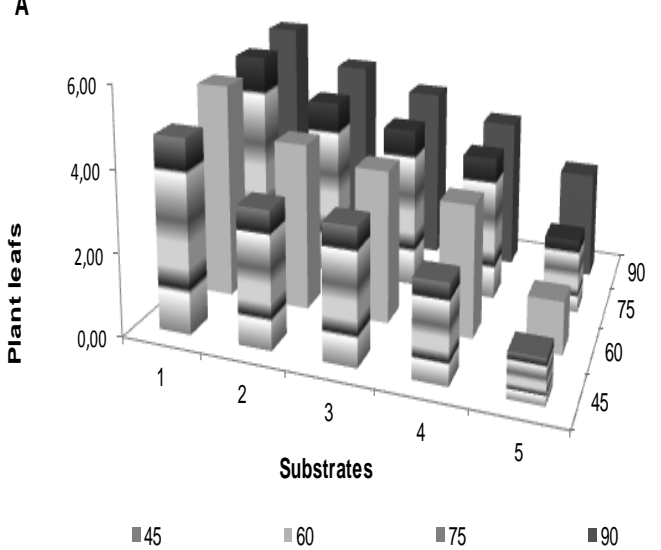

B

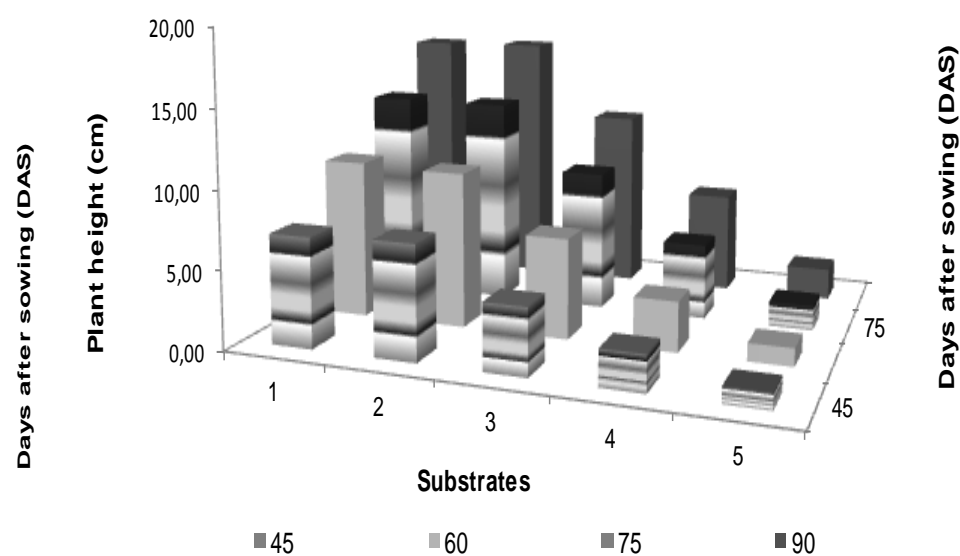

Figure 2. Leaves (A) plant height (B) of Cape gooseberry plants in response to different substrate compositions, Federal Technological University of Parana, Campus of Dois Vizinhos, 2009. Substrate 1: Soil + chicken manure (2:1 v/v) 2: Soil + chicken manure + sand $(2: 1: 1 \mathrm{v} / \mathrm{v} / \mathrm{v}) ; 3$ : Soil + humus + vermiculite $(2: 1: 1 \mathrm{v} / \mathrm{v} / \mathrm{v}) ; 4$ : Soil + humus (2:1 v/v); 5 : Macplant ${ }^{8}$ (commercial substrate).

Table 2. Evolution of the number of leaves per Cape gooseberry plant in response to different substrate combinations, Federal Technological University of Parana, Campus of Dois Vizinhos, 2009.

\begin{tabular}{lcccc}
\hline Substrate & 45 DAS & 60 DAS & 75 DAS & 90 DAS \\
\hline Soil + chicken manure (2:1) & $4.8^{\mathrm{a}}$ & $5.4^{\mathrm{a}}$ & $5.3^{\mathrm{a}}$ & $5.8^{\mathrm{a}}$ \\
Soil + chicken manure + sand (2:1:1) & $3.4^{\mathrm{ab}}$ & $4.1^{\mathrm{ab}}$ & $4.5^{\mathrm{ab}}$ & $4.9^{\mathrm{ab}}$ \\
Soil + humus + vermiculite (2:1:1) & $3.3^{\mathrm{ab}}$ & $3.7^{\mathrm{b}}$ & $4.0^{\mathrm{b}}$ & $4.4^{\mathrm{ab}}$ \\
Soil + humus (2:1) & $2.3^{\mathrm{bc}}$ & $3.2^{\mathrm{b}}$ & $3.6^{\mathrm{b}}$ & $3.8^{\mathrm{bc}}$ \\
Macplant $^{\mathrm{B}}$ ( commercial substrate) & $1.3^{\mathrm{c}}$ & $1.4^{\mathrm{c}}$ & $1.8^{\mathrm{c}}$ & $2.5^{\mathrm{c}}$ \\
Means & 2.99 & 3.56 & 3.89 & 4.25 \\
Pr > Fc & 0.0008 & 0.0001 & 0.0001 & 0.0014 \\
CV $(\%)$ & 24.87 & 18.72 & 16.13 & 17.68 \\
\hline
\end{tabular}

Means followed by the same letter do not differ statistically by the Tukey test $t 5 \%$ of probability.

percentage magnitude were evident, mainly for the substrates that contain humus in it composition, however, the less emergence percentage was observed with the commercial substrate.

Similar results were obtained by Oliveira et al. (2009) studying the germination of soursop (Annona muricata) seeds found that, the use of humus in substrate composition improved nutritional quality of the substrate

As can be observed in Figure 2, the seedlings that emerged in the substrates with soil + chicken manure and with soil + chicken manure + sand, presented higher initial development in relation to the humus substrates (Table 2).

The higher initial growth of seedlings was observed with the use of chicken manure in the mix with soil and with soil + sand. This can be due to the higher availability of nutrients, increasing the growth of seedlings in relation to other substrates (Figure 2). Lucena et al. (2009) also observed that, the manure of chicken promoted the development of Pacara Earpod (Enterolobium cotortosilicum) seedlings with higher evidence when compared to obtained values for the control.

All the evaluated substrates, except the commercial substrate used in this study (Macplant ${ }^{\circledR}$ ), have advantages related to the physical properties, which we can emphasize the greater availability of water and the drainage of the excess water.

Table 2 shows that, the seedlings cultivated in the substrate soil + chicken manure had higher number of leaves in relation to those cultivated with other substrates, since the first evaluation. Kuhn et al. (2012) indicates that, at 45 DAS the Cape gooseberry seedlings conducted in commercial substrate plus the mix with vermiculite presented average of 3.5 leaves per plant.

Contrary to our results, Neves et al. (2010) found that, the use of substrate with soil + chicken manure presented 
Table 3. Plant height of Cape gooseberry plants in response to different substrate compositions, in the period of 45 to 90 DAS, Federal Technological University of Parana, Campus of Dois Vizinhos, 2009.

\begin{tabular}{|c|c|c|c|c|}
\hline Substrate & 45 DAS & 60 DAS & 75 DAS & 90 DAS \\
\hline Soil + chicken manure $(2: 1)$ & $7.5^{\mathrm{a}}$ & $10.5^{\mathrm{a}}$ & $13.5^{\mathrm{a}}$ & $16.8^{\mathrm{a}}$ \\
\hline Soil + chicken manure + sand $(2: 1: 1)$ & $7.0^{\mathrm{a}}$ & $10.3^{\mathrm{a}}$ & $13.5^{\mathrm{a}}$ & $16.8^{\mathrm{a}}$ \\
\hline Soil + humus + vermiculite $(2: 1: 1)$ & $4.3^{b}$ & $6.8^{\mathrm{b}}$ & $9.1^{\mathrm{b}}$ & $11.8^{\mathrm{ab}}$ \\
\hline Soil + humus $(2: 1)$ & $2.5^{\mathrm{bc}}$ & $3.5^{\mathrm{c}}$ & $4.9^{\mathrm{c}}$ & $6.5^{\mathrm{bc}}$ \\
\hline Macplant $^{\circledR}$ ( commercial substrate) & $1.0^{\mathrm{C}}$ & $1.0^{\mathrm{d}}$ & $1.6^{\mathrm{c}}$ & $2.3^{b c}$ \\
\hline Means & 4.45 & 6.4 & 8.53 & 10.8 \\
\hline $\operatorname{Pr}>\mathrm{Fc}$ & 0.0000 & 0.0000 & 0.0000 & 0.0000 \\
\hline CV (\%) & 20.72 & 16.88 & 22.22 & 27.05 \\
\hline
\end{tabular}

Means followed by the same letter do not differ statistically by the Tukey test $t 5 \%$ of probability.

Table 4. Parameters of grow of Cape gooseberry plants in response to different substrate compositions in the production of seedlings, Federal Technological University of Parana, Campus of Dois Vizinhos, 2009.

\begin{tabular}{lccc}
\hline Substrate & $\begin{array}{c}\text { Dry mass of root system } \\
(\mathbf{A})(\mathbf{g})\end{array}$ & $\begin{array}{c}\text { Dry mass of } \\
\text { shoot system (B) (g) }\end{array}$ & Relation (A)/(B) \\
\hline Soil + chicken manure (2:1) & $0.147^{\mathrm{a}}$ & $0.287^{\mathrm{a}}$ & $1.93^{\mathrm{ab}}$ \\
Soil + chicken manure + sand (2:1:1) & $0.107^{\mathrm{a}}$ & $0.244^{\mathrm{a}}$ & $2.46^{\mathrm{a}}$ \\
Soil + humus + vermiculite (2:1:1) & $0.058^{\mathrm{b}}$ & $0.126^{\mathrm{b}}$ & $2.37^{\mathrm{a}}$ \\
Soil + humus (2:1) & $0.024^{\mathrm{bc}}$ & $0.045^{\mathrm{bc}}$ & $1.99^{\mathrm{ab}}$ \\
Macplant ${ }^{\mathrm{B}}$ ( commercial substrate) & $0.006^{\mathrm{c}}$ & $0.006^{\mathrm{c}}$ & $1.19^{\mathrm{b}}$ \\
Means & 0.069 & 0.141 & 1.99 \\
Pr > Fc & 0.0000 & 0.0000 & 0.0059 \\
CV (\%) & 30.55 & 30.84 & 20.2 \\
\hline
\end{tabular}

Means followed by the same letter don't differ statistically by the Tukey test t $5 \%$ of probability.

lesser values in relation to other substrates in moringa (Moringa oleifera Lam) seedlings for the following variables: plant height, index of emergence velocity, dry mass of roots and dry mass of shoots.

In Table 3 can be observed that, the height of plants in substrates containing humus were statistically different, being inferior according to the Tukey test in all conducted evaluations, being only superior to the commercial substrate Macplant ${ }^{\circledR}$ in almost all evaluations.

As can be seen in Table 4, the variables dry mass of shoot system and root system presented higher values when substrates with presence of chicken manure were used, being the inferior means presented by the Macplant ${ }^{\circledR}$ substrate.

David et al. (2008) show that, the application of organic matter in chicken manure provides the development and production of dry matter in passion fruit plants. This can be result of the nutrient concentration, according to Severino et al. (2006), the chicken manure present in it composition mainly $2.95 \%$ of nitrogen, $3.97 \%$ of phosphorus, $1.10 \%$ of potassium, $4.71 \%$ of calcium and $6.93 \%$ of magnesium. However, Neves et al. (2010) observed lower values of dry mass for the substrate from chicken manure in relation to other organic materials.

Regarding to the inclusion of small fruits in the last years of Brazilian fruit production, studies are important in order to conduct the emergence of seedlings in adequate conditions, as indeed, when these conditions are obtained, the development of culture is improved.

Besides, in the southwest region of Parana, there is a significant production of many different byproducts from agricultural origin, being that the replacement of commercial substrates by compounds produced in the farms can decrease the production expenses, in this way increasing the economic gain of the production of fruits. These knowledge can also be used in the formulation of new substrates, with the purpose of using available raw materials and distribute them in other productive centers.

\section{Conclusions}

The use of substrates as soil + humus + vermiculite $(2: 1: 1 \mathrm{v} / \mathrm{v} / \mathrm{v})$ and soil + humus (2:1 v/v) provided higher emergence of Cape gooseberry seedlings. The initial development of seedlings is higher in substrates 
containing chicken manure. The isolated use of the commercial substrate Macplant ${ }^{\circledR}$ must be avoided in the propagation of this culture, because it can affect the emergence and initial development of $P$. peruviana $L$. negatively.

\section{REFERENCES}

Alvino FO, Rayol BR (2007). Different substrate effects in the germination of Ochroma pyramidale (cav. ex lam.) urb. (bombacaceae). Ciên. Flor. 17(1):71-75.

Andrade ACS, Pereira TS, Fernandes MJ, Cruz APM, Carvalho ASR (2006). Germination substrate, temperature and post-seminal development of Dalbergia nigra seeds. Braz. Agric. Res. 41(3):517523.

Andrade L (2008). Physalis or uchuva - Fruit from Colombia reach Brazil. Rural Mag. 38:11-12.

Brasil (2009). Ministry of Agriculture, Livestock and Food Supply. Rules for seed testing. Ministry of Agriculture, Livestock and Food Supply. Agriculture Defense Department. Brasília, DF: Mapa/ACS. P. 395.

Castro PRC, Kluge RA, Peres LEP (2005). Manual of plant physiology: Theory and practice. Piracicaba: Agronômica Ceres. P. 650.

Chaves AC, Schuch MW, Erig AC (2005). In vitro establishment and multiplication of Physalis peruviana L. Ciência e Agrotecnologia 29(6):1281-1287

David MA, Mendonça V, Reis LL, Silva EA, Tosta MS, Freire PA (2008). Effect of single superphosphate and organic matter doses on the growth of yellow passion fruit seedlings. Pesquisa Agropecuária Trop. 38(3):147-152.

Dias MA, Lopes JC, Corrêa NB, Dias DCFS (2008). Pepper seed germination and seedling development due to substrate and water sheet. J. Seed Sci. 30(3):115-121.

Díaz LA, Fischer G, Pulido SP (2010). Coco peat as a substitute for peat moss in the production of Cape gooseberry (Physalis peruviana L.) seedlings. Colomb. J. Hortic. Sci. 4(2):153-162.

Ferraz ABF, Limberger RP, Bordignon S, von Poser GL, Henriques AT (2005). Essential oil composition of six Hypericum species from Southern Brazil. Flav Frag J 20: 335-339.

Inmet (2012). Weather Station A843 de Dois Vizinhos, PR. Available at <http://www.inmet.gov.br/sonabra/maps/pg_automaticas.php> Acesso em: 27 de Março de 2012.

Kuhn PR, Kulczynski SM, Bellé C, Koch F, Werner CJ (2012). Initial development of seedlings physalis (Physalis peruviana) through the seeds of fruits mature and green under different substrates. Encyclopedia Biosph. 8(15):1378-1385.

Lima CSL, Gonçalves MA, Tomaz ZFP, Rufato AR, Fachinello JC (2010). Periods replanting and training systems of Cape-gooseberry. Ciência Rural 40(12):2472-2479.

Lucena AMA, Costa FX, Silva H, Guerra HOC (2009). Germination of forest species on substrates fertilized with organic matter. Revista de Biologia e Ciências da Terra 4(2):208-212.
Mota RV (2006). Characterization of black-berry juice prepared in a domestic extractor. Food Sci. Technol. 26(2):303-308.

Muniz J, Kretzschmar AA, Rufato L, Pelizza TR, Marchi T, Duarte AE, Lima APF, Garanhani $F$ (2011). Conduction systems for physalis production in southern Brazil. Braz. Mag. Fruit Cult. 33(3):830-838.

Nascimento WM, Sousa RB, Silva JBC, Carrijo AO (2003). Seed germination and stand establishment of vegetable crops in different substrates under tropical conditions. Acta Horticulturae 609:483-485.

Neves JMG, Silva HP, Duarte RF (2010). Use of alternative substrates for production of Seedlings moringa. Green Mag. 5(1):173-177.

OLIVEIRA DCSG, WERREN JH, VERHULST EC, GIEBEL JD,KAMPING A, BEUKEBOOM LW, VAN DE ZANDE L (2009).Identification and characterization of the doublesex gene of Nasonia. Insect Mol. Biol. 18: 315-324.

Rodrigues E, Rockenbach II, Cataneo C, Gonzaga LV, Chaves ES, Fett $R$ (2009). Mineral sand essential fatty acid sof the exotic fruit Physalis peruviana L. Rev. Food Sci. Technol. 29(3):642-645.

Sas Institute (1999). SAS user's guide statistics: version 8.0 edition. Cary. P. 956.

Severino LS, Lima RLS, Beltrão NEM (2006). Chemical composition of eleven organic materials used in substrates for seedling production. Comunicado Técnico 278, Ministerio da Agricultura Pecuaria e Abastecimento. Campina Grande. P. 5.

Taiz L, Zeiger E (2009). Plant physiology. 5. ed. Massachusetts: Sinauer. P. 819.

Velasquez HJC, Giraldo OHB, Arango SSP (2007). Preliminary study of mechanical resistance to fracture and firmness force for uchuva (Physalis peruviana L) fruits. Revista Facultad Nacional de Agronomía -Medellín 60(1):3785-3796.

Wagner-Júnior A, Santos CEM, Silva JOC, Alexandre RS, Negreiros JRS, Pimentel LD, Álvares VS, Bruckner CH (2006). Influence of soaking water ph and substrates in the seeds germination and initial development of the sweet passion fruit. Curr. Agric. Sci. Technol. 12(2):231-236. 